\title{
地震力により部分圧縮を受ける土台の抵抗能力と破壊性状 RESISTING PERFORMANCE AND FRACTUAL BEHAVIOR BY SILL EMBEDMENT DURING EARTHQUAKES
}

\author{
秋元 星*, 五十田 博**, 松田昌洋***, 槌 本敬 大**** \\ Sho AKIMOTO, Hiroshi ISODA, Masahiro MATSUDA \\ and Takahiro TSUCHIMOTO
}

\begin{abstract}
In this study, many partial compression tests under large deformation were conducted to grasp the damage and safety limit and to evaluate the strength value. The specimen consists of full surface, edge part and center part compression of the sill with/without column and so on. The shaking table tests were also conducted to confirm the damage and safety limit. Results of these static and dynamic loading tests are summarized as follows;

1) The strength obtained from all material tests is satisfied with the strength value in accordance with Japanese Building Standard Law, but the strength in a few of full surface compression dropped the load after the given deformation of $60 \mathrm{~mm}$.

2) Safety capacity for supporting vertical load is confirmed under more than strength value in the shaking test. Safety limit deformation is proposed around $20 \mathrm{~mm}$ and it is $1.16-1.82$ time of timber and 1.40 to 2.34 times of glulam in the current strength.
\end{abstract}

Keywords : Embedment, Standard strength, Partial compression, shaking table test, Column-sill joint, Laminated timber めり込み，基準強度，部分圧縮，振動台実験，土台，集成材

\section{1. はじめに}

木材の引っ張りや曲げといった基本的な材料の力学的挙動は、塑 性化に至らず急激に荷重が低下するか、塑性化したとしても勒性は さほど大きくなく、脆性的に破壊にいたる場合が多い。一方で、繊 維直角方向の部分圧縮である、いわゆる、めり込み挙動は、降伏応 力度（以下、比例限応力度とする）を超えた後も、耐力低下寸るこ となく変形が進行する勒性のある挙動を呈する。この優れた勒性を 設計に活かすことを目的に、これまでいくつかの研究がなされてお り、その代表的なものは、稲山による実験に基づきバイリニア特性 を定式化した研究 1)など、野口による有限要素法を用いた許容耐力に 関する研究 2)など、棚橋による解析的な研究 3) な゙、などである。

ここで、典型的なめり込みの荷重変形関係を図 1 に示寸。めり込 み挙動は、降伏の後再び荷重が上昇する（以後この現象をハードニ ングと称する) パターン（1)と考えられている。また、めり込みの基 準強度についてその背景を確認すると、文献 4)では、「(前略) 許容 応力度は気乾状態の無欠点小試験体による比例限度応力度に基づき (後略)」とある。比例限度応力度を短期許容応力度とみなせば、基 準強度はその 1.5 倍であり、文献5)では次の式で説明している。
めり込み基準強度 : $F_{c V}={ }_{0} F_{c V} \times 1.00(\alpha) \times 1.5$

ここで、 $o F_{c V}$ は比例限応力度の平均值、 $\alpha$ は欠点による低減係数 である。つまり、基準強度は直接的に実験で得られた值ではなく、 短期許容応力度に相当する比例限応力度を実験で得て、基準強度と 比例限応力度の比率 $1.5: 1.0$ をあてはめたものである。これは、前 述した図 1 のパターン(1)ようにバイリニア挙動の後に荷重が上昇 しつづけるのであれば問題はないが、パターン（3)となると、実際に は基準強度に対応する值が存在しないことも考えられ、比例限度を 1.5 倍した基準強度の状態は明確ではない。

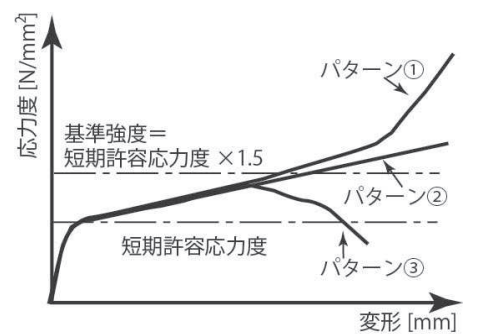

図 1 典型的なめり込みの荷重変位形関係
* 信州大学大学院 修士課程(当時)

** 京都大学生存圈研究所 教授 建築研究所 客員研究員・博士 (工学)

*** 信州大学工学部 助教・博士 (工学)

**** 建築研究所材料研究グループ 上席研究員・博士 (農学)
(Former) Grad. Stud., Graduate School of Engineering, Shinshu University Prof., RISH, Kyoto University

Visiting Researcher, BRI, Dr.Eng.

Assist. Prof., Faculty of Eng., Shinshu University, Dr.Eng.

Chief Research Engineer, Dept. of Building Materials and Components, Building Research Institute, Dr.Agr. 
また、木造軸組工法住宅の許容応力度計算法 6)では、「降伏点を少 し超えた程度では材に損傷は生じず、材表面の繊維が損傷して凹ん だ跡が残るのは、圧縮応力が材料強度（基準強度と同意と考えられ る）を超えてめり込み変位が $5 \mathrm{~mm}$ から $10 \mathrm{~mm}$ に達した後である。 （中略）土台のめり込みに対する検定は、短期水平力に対する損傷 限界や大地震に対する安全限界についてはクリティカルな要因とは なり得ず、(後略)」としている。仮に基準強度を超えた後に材に損 傷が起こるとしても、大地震時の変形制限や短期時の検定において 何らかの措置が必要ではないか、と疑問に思うところもある。

そこで本研究は、材料実験と振動台実験を実施し、土台のめり込 みについて比例限度を超え基準強度に至り、さらにそれを超えた後 の挙動を明らかにするものである。材料実験はこれまで実施してい ない大変形時のめり込み挙動を得ることを目的に実施した。振動台 実験は、基準強度を超える衝撃的な応力が作用した際、鉛直支持能 力に支障をきたすことがないか、を確認することを目的に実施した。

\section{2. 材料実験}

\section{1 実験概要}

土台に用いる $105 \mathrm{~mm} \times 105 \mathrm{~mm} \times 3,915 \mathrm{~mm}$ の製材と集成材を 50 本ずつ用意し、それを切り出し、試験体を製作した。樹種は、製材 がベイヒ、集成材がオウシュウアカマツであり、等級は製材が E90、 集成材は同一等級構成集成材 E105-F300 である。図 2 に試験体の 切り出し方法を示した。1 本の材から全面圧縮試験体、圧縮治具に 鋼板を用いて圧縮寸る鋼板圧縮試験体、木材の柱を加力治具に用い て材端部、そして中間部を圧縮する試験体、それぞれ 3 体、2 体、2 体、2 体を採取した。その結果、試験体総数は 900 体となり、その 内訳は製材と集成材でそれぞれ、全面圧縮試験体 150 体、鋼板圧縮 試験体を材端、中間圧縮用に分け、それぞれ 50 体、柱を圧縮する 試験体が端部と中間で、それぞれ 100 体である。図 3 に試験体の形 状を示す。ここで、柱を加力する圧縮試験の端部の試験体（以降、 材端柱圧縮試験体）は断面 $57 \mathrm{~mm} \times 30 \mathrm{~mm}$ 長さ $40 \mathrm{~mm}$ の寄ほぞ、土 台の中間部を圧縮する試験体（以降、中間柱圧縮試験体）は中柱を 想定し断面 $88 \mathrm{~mm} \times 30 \mathrm{~mm}$ 長さ $50 \mathrm{~mm}$ の短ほぞとした。以降の考察 において、柱を圧縮する試験体の応力度は土台のほぞ加工部分の面 積を除外している。ほぞの深さは、ほぞ長さ+10mm とした。材端 柱圧縮試験では $50 \mathrm{~mm}$ 、中間柱圧縮試験では $60 \mathrm{~mm}$ と異なる。加え て柱で圧縮することは共通だが、柱のほぞのオス加工のない状態で 実験を半数実施した。この試験体を以降、ほぞ無と称し、柱にほぞ のオス加工のあるものをほぞ有とする。柱は、製材はスギ、集成材 はスプルースである。なお、発注時、「土台に使う」という以外特段 の配慮はせず、ほぞ穴の位置も集成材で積層方向に加工するという 以外、指定はしていない。また、製材では心持ちでない材がある。 一般にベイヒ土台において心持ちでない材が使われることのあるの は確認済みである。載荷は単調載荷とし、試験法 7では、めり込み 変位の計測を $20 \mathrm{~mm}$ までとしたものもあるが、本研究では、終局状 態を検討するため、 $60 \mathrm{~mm}$ 程度まで加力、計測を実施した。

\section{2 荷重変形関係の分類整理}

実験結果を整理するにあたり、荷重変形関係のパターンを整理し た。基本は図 1 におけるパターン(1)ようにハードニングするもの、
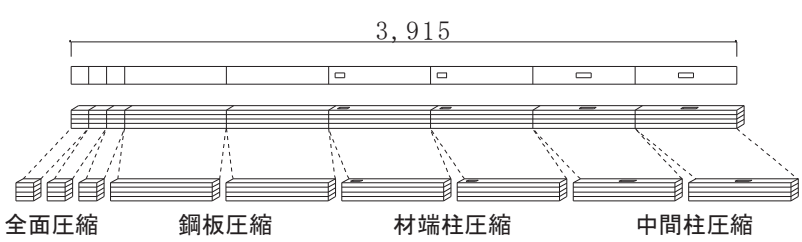

図 2 試験体の切り出し方法
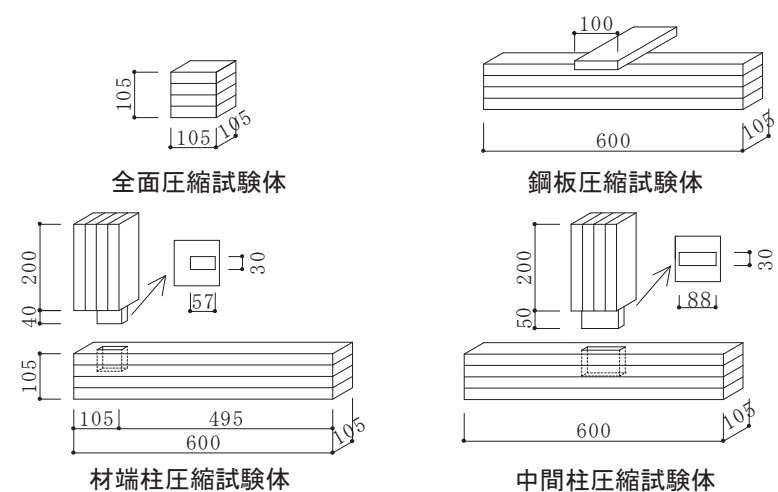

鋼板圧縮試験体

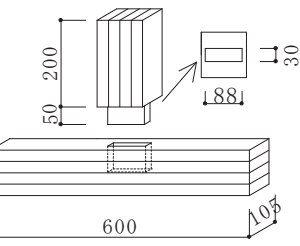

中間柱圧縮試験体

図 3 試験体
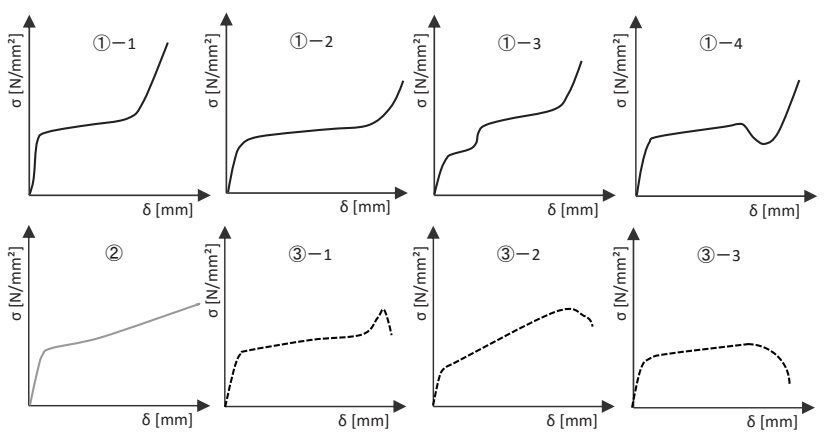

\begin{tabular}{l|l} 
パターン & 挙動 \\
\hline (1) & めり込み変位 $40 \mathrm{~mm}$ 付近でハードニングする。 \\
\hline (1)-2 & $50 \mathrm{~mm}$ 付近でハードニングを生じる。 \\
\hline (1)-3 & めり込み変位 $10 \mathrm{~mm}$ 付近で剛性上昇する。 \\
\hline (1)-4 & ハードニング手前で一度、荷重低下する。 \\
\hline (2) & 二次勾配のまま終局を迎える。 \\
\hline (3)-1 & ハードニングの兆し直後に荷重低下する。 \\
\hline (3)-2 & 降伏後、荷重が上昇するが、途中で荷重低下する。 \\
\hline (3)-3 & 二次剛性が低く、途中で荷重低下する。
\end{tabular}

図 4 荷重変形の細分類

パターン(2)のように $60 \mathrm{~mm}$ 程度までの加力においてハードニング も荷重低下もみられないもの、そしてパターン(3)のように荷重低下 寸るものの 3 つに大きく分類された。そして、パターン (1) と (3)では いくつかの派生がみられたのでそれらをさらに分類した。図 4 に細 分類した結果を示す。パターン(1)では、ハードニングした変位に違 いがみられたので $35 \sim 45 \mathrm{~mm}$ 程度までと $50 \mathrm{~mm}$ 程度以降に分けた。 また、ほぞのある試験体ではほぞの影響がみられたものもあったの で、それも細分類に加え、さらにハードニングの手前で荷重低下寸 るものがあり、それを加えた。パターン(3)では 2 次剛性に大きく違 いがみられ、2 次剛性がある程度大きく、さらに一度ハードニング しかけその後荷重低下するもの、ハードニングせず荷重低下寸るも のに分けた。以後、上記の分類を基に、それぞれの試験体別に考察 を進める。また、以後の考察では節の影響について、特段それだけ 
を取り出して言及をしていないので、ここでまず注記する。表 1 に 鋼板圧縮試験で中間を加力した際に加力下部の影響範囲と考えられ る部分に節があるもの（以降、節あり）と、ないもの（以降、節な し）のそれぞれの比例限応力度の平均值を示した。製材では、節あ りの方が 2 倍程度高い值を示したが、集成材では積層ラミナごとの 圧縮変形に違いがあるため、1.2 倍程度であった。図 5 のように圧 縮面の節が死節であると、形状を保ったまま外側にはらみだし、生 節の場合には、節内部または、周辺部に割れがみられた。そして、 飛び出したことによる間隙の影響や亀裂によって、それ以降の変形 で荷重低下したものもあった。このようにめり込み挙動に節が大き く影響する。詳細な検討は稿を改め論じたい。

表 1 節の有無による影響 ※鋼板圧縮試験より

\begin{tabular}{l|c|c|c}
\multirow{2}{*}{} & \multicolumn{2}{|c|}{ 比例限応力度 $\left[\mathrm{N} / \mathrm{mm}^{2}\right]$} & \multirow{2}{*}{ 比 } \\
\cline { 2 - 3 } & 節あり & 節なしり & 節なし \\
\hline 製材 & 11.28 & 5.44 & 2.07 \\
\hline 集成材 & 6.66 & 5.36 & 1.24
\end{tabular}

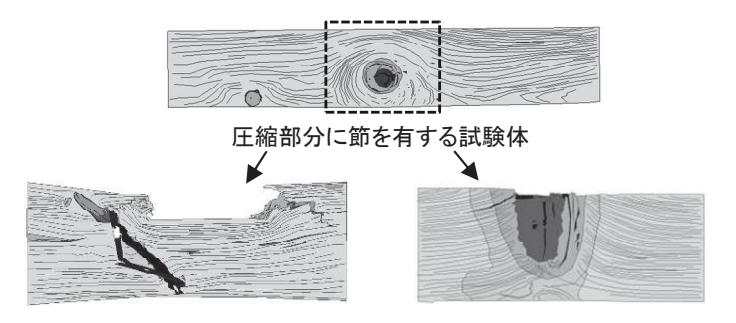

死節 : 形状を保ったまま飛び出す

生節 : 節内部または周辺部に亀裂

図 5 節あり試験体の変形挙動

全面圧縮試験 まず、同一材から切り出した試験体について挙動 を比較する。図 6 は典型的な 2 種類の荷重変形関係を比較したもの である。（a）はほぼ同じ挙動を示し、図 6 （b）は異なる挙動を示し たものである。同一材から取り出した材であっても、同じ挙動とは ならない場合があったが、その違いを現段階では特定できていない。

図 7 にはすべての荷重変形関係とそのパターンの分類結果を示す。 製材、集成材ともにほとんどの試験体において $40 \mathrm{~mm}$ 程度でハード ニングをしており、最終的に基準強度を大きく上回る結果となった。 図 8 に破壊性状を示す。製材は、外周部に広がりつぶれたものと年 輪傾斜の影響を強く受け、全体的に圧縮が進むものがみられた。集 成材では、原形をとどめず全体的に圧壊したものがあった。パター ン (1)-2 には、圧壊した材の一部がハードニングしたものも含まれ るが、全体の 1 割と少なく、ある層だけの破壊が進むというものが 大半であった。層ごとに剛性、降伏点が異なるため、このような抵 抗挙動になったと考えられる。

鋼板圧縮試験図 9 に荷重変形関係とそのパターンを示す。全体 では、およそ 9 割が全面圧縮と同様に $40 \mathrm{~mm}$ 付近でハードニングが みられた。材端部の挙動パターンは集成材、製材とも同じ傾向を示 し、ほとんどがハードニングを生じたが、1 2 割程度は、荷重低下 しないものの明確なハードニングを生じることなく $60 \mathrm{~mm}$ までめ り込むパターン(2)の挙動を示した。中間部では、製材でハードニン グしないものが 4 割程度あった。集成材は、製材に比べるとばらつ きが小さく、製材、集成材ともに圧縮面のめり込みが進展すること によって材端部に引張による割裂が生じる破壊性状を示した。
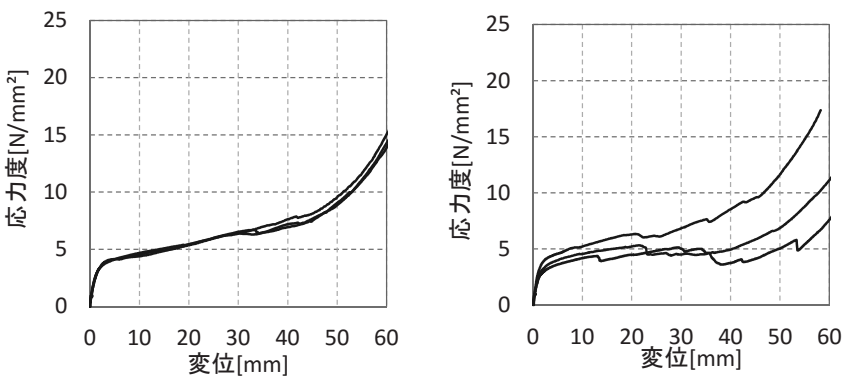

(a) 同じ挙動を示した試験体

(b) 異なる挙動を示した試験体 図 6 同一材から切り出した試験体の挙動
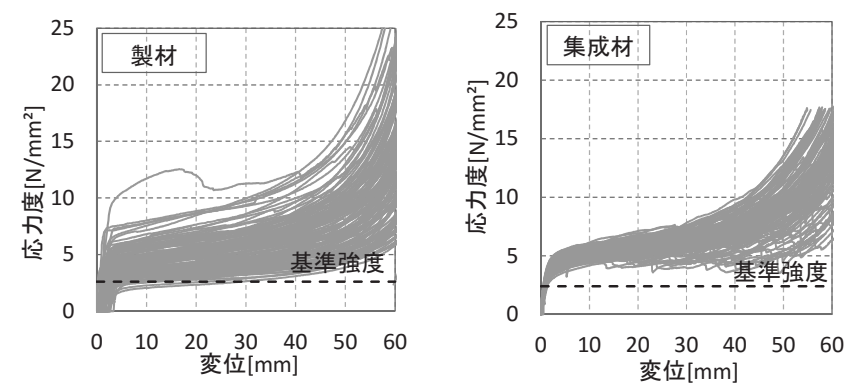

\begin{tabular}{l|c|c} 
パターン & 製材 $(149$ 体 $)$ & 集成材 $(150$ 体 $)$ \\
\hline (1)-1 & 122 & 125 \\
\hline (1)-2 & 27 & 25
\end{tabular}

図 7 荷重変形関係とそのパターン（全面圧縮）

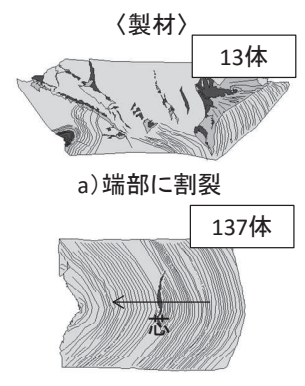

b) 全体的に圧縮

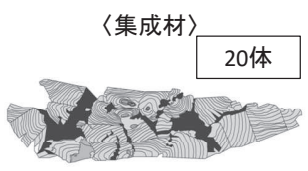

a) 全体的に圧壊

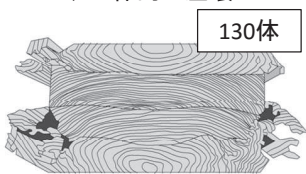

b) 端部のみに割裂
図 8 破壊性状（全面圧縮）
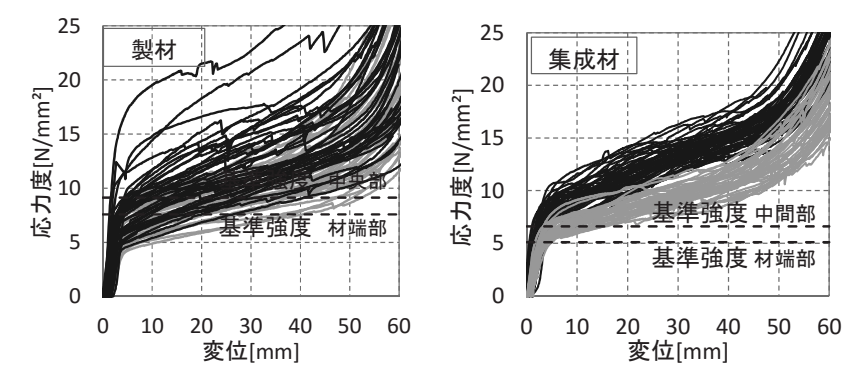

\begin{tabular}{|c|c|c|c|c|}
\hline & - & 1間部 & 材端部 & \\
\hline \multirow[t]{2}{*}{ パターン } & \multicolumn{2}{|c|}{ 製材（99 体） } & \multicolumn{2}{|c|}{ 集成材（100 体） } \\
\hline & 材端部 (49) & 中間部 $(50)$ & 材端部（50） & 中間部 (50) \\
\hline (1) -1 & 37 & 30 & 36 & 39 \\
\hline (1) -2 & 6 & 1 & 6 & 6 \\
\hline (2) & 6 & 19 & 8 & 5 \\
\hline
\end{tabular}

図 9 荷重変形関係とそのパターン（鋼板圧縮） 

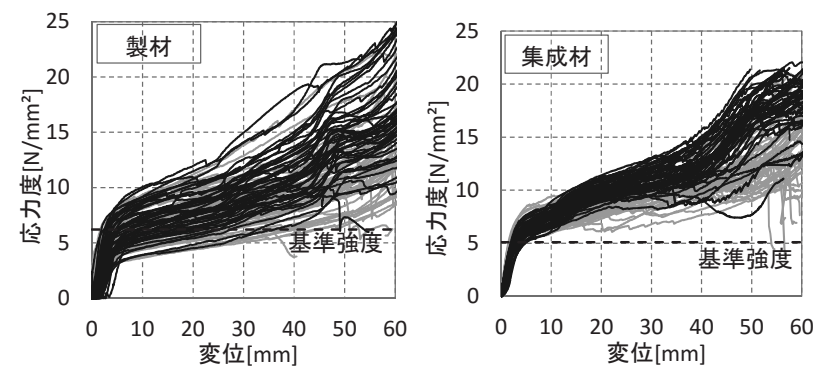

一ほぼ有——ぼ無

\begin{tabular}{l|c|c|c|c}
\multirow{2}{*}{ パターン } & \multicolumn{2}{|c|}{ 製材 $(100$ 体 $)$} & \multicolumn{2}{|c|}{ 集成材 $(100$ 体 $)$} \\
\cline { 2 - 5 } & ほぞ無 $(50)$ & ほぞ有 $(50)$ & ほぞ無 $(50)$ & ほぞ有 (50) \\
\hline (1)-1 & 39 & 29 & 31 & 19 \\
\hline (1)-2 & 1 & 3 & 4 & 0 \\
\hline (1)-3 & 0 & 0 & 0 & 20 \\
\hline (1)-4 & 0 & 0 & 0 & 1 \\
\hline (2) & 8 & 12 & 7 & 2 \\
\hline (3)-1 & 0 & 3 & 2 & 5 \\
\hline (3)-2 & 1 & 1 & 6 & 3 \\
\hline (3)-3 & 1 & 2 & 0 & 0
\end{tabular}

図 10 荷重変形関係とそのパターン（材端柱圧縮）

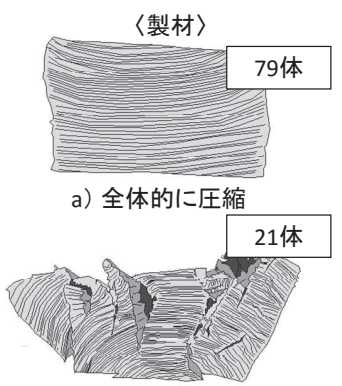

b）端部に割裂
〈集成材〉

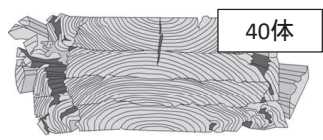

a) 全体的に圧縮

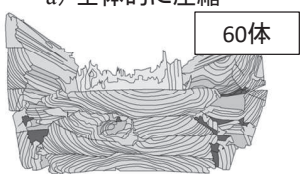

b）中央部のみの圧縮

図 11 破壊性状（材端柱圧縮）

材端柱圧縮試験図10 亿荷重変形関係とそのパターンを示す。 ほとんどの試験体でハードニングを生じるか、二次剛性のまま 60mm に達するパターン (1)、(2)であった。パターン(3)のように荷重 低下したものもあったが、基準強度を下回ることはなかった。パタ ーン(1)-3 は、集成材のほぞ有特有であり、約 4 割の試験体でめり 込夕変位 $10 \mathrm{~mm}$ 付近にて、荷重の上昇がみられた。製材では明確に この挙動を確認できなかった。ほぞの土台加工下部への接触が原因 と考えられる。土台のほぞ加工された部分は圧縮される面積が小さ く変形が進むが、製材は全体的に変形が進んでいる印象、集成材は ある層で変形が進むという印象の差が見られ、それが荷重変形の違 いとして表れた、とも考えられるが、詳細は不明である。図 11 に 破壊性状を示す。全体的に圧縮が進むものと中央部のみで進むもの、 さらに柱材が割れ土台に割裂を生じさせ端部にはらむ破壊がみられ た。パターン(3)の荷重低下は、土台の割裂、柱材が先行破壊、圧縮 部分に節が存在しており、それが抜けたことなどが原因である。

中間柱圧縮試験図 12 に荷重変形関係とそのパターンを示寸。 ほぞ有では $40 \mathrm{~mm}$ 付近で剛性が上昇した。また、ほぞ無に比べ降伏 後の剛性が高く、集成材のみめり込み変位 $10 \mathrm{~mm}$ 付近にて、荷重上 昇を示すパターン(1)-3 が、6 割と材端柱圧縮より多く存在した。
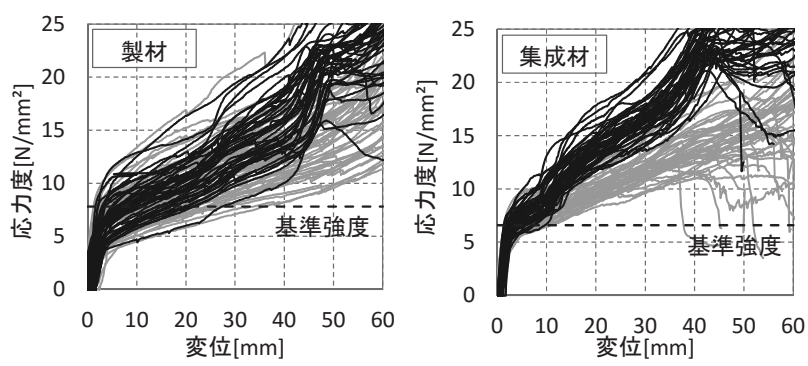

\section{—ほぼ有 ——ぞ無}

\begin{tabular}{l|c|c|c|c}
\multirow{2}{*}{ パターン } & \multicolumn{2}{|c|}{ 製材 (100 体) } & \multicolumn{2}{|c|}{ 集成材 (99 体) } \\
\cline { 2 - 5 } & ほぞ無 (50) & ほぞ有 (50) & ほぞ無 (50) & ほぞ有 (49) \\
\hline (1)-1 & 22 & 34 & 6 & 2 \\
\hline (1)-2 & 1 & 0 & 0 & 0 \\
\hline (1)-3 & 0 & 0 & 1 & 29 \\
\hline (2) & 27 & 6 & 30 & 1 \\
\hline (3)-1 & 0 & 7 & 0 & 16 \\
\hline (3)-2 & 0 & 3 & 13 & 1
\end{tabular}

図 12 荷重変形関係とそのパターン（中間柱圧縮）
〈製材〉

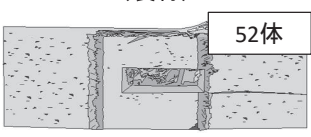

a）面外方向のはらみ

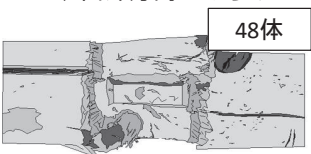

b）中央部の圧縮·土台割裂
〈集成材〉

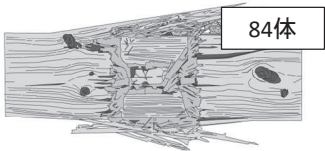

a）面外方向のはらみ

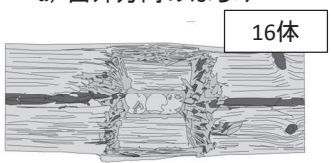

b）中央部の圧縮·土台割裂
図 13 破壊性状（中間柱圧縮）

表 2 終局状態における柱と土台の割裂数

\begin{tabular}{|c|c|c|c|c|c|c|}
\hline & & & 柱材のみ & 土台のみ & 両方 & 割裂なし \\
\hline \multirow{4}{*}{ 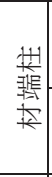 } & \multirow[t]{2}{*}{ 集成材 } & ほぞ有 & 14 & 2 & 1 & 32 \\
\hline & & ほぞ無 & 26 & 1 & 1 & 22 \\
\hline & \multirow[t]{2}{*}{ 製材 } & ほぞ有 & 2 & 12 & 17 & 19 \\
\hline & & ほぞ無 & 2 & 9 & 11 & 28 \\
\hline \multirow{4}{*}{ 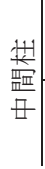 } & \multirow[t]{2}{*}{ 集成材 } & ほぞ有 & 17 & 5 & 8 & 20 \\
\hline & & ほぞ無 & 32 & 1 & 2 & 15 \\
\hline & \multirow[t]{2}{*}{ 製材 } & ほぞ有 & 12 & 4 & 5 & 29 \\
\hline & & ほぞ無 & 12 & 6 & 7 & 25 \\
\hline
\end{tabular}

ほぞ無の半数以上は、明確なハードニングせず終局を迎えた。集成 材では、パターン(3)-2の挙動を示し荷重低下した試験体が 2 割程 度あり、荷重低下の原因は、柱材の先行破壊によるものであった。 図 13 に破壊性状を示す。破壊性状とハードニングの有無には関係 性がみられず、土台が面外方向に膨らむものと、中央部のみ圧縮が 進み、土台の割裂を伴うものがあった。

表 2 に終局状態における柱と土台の割裂数を示す。柱材の割裂は、 ほぞ無に多く存在した。ほぞ有同様、土台にほぞ穴があり、ほぞ穴 端部に応力が集中してしまうことが原因である。一方、土台に割裂 を生じた試験体は、ほぞ有の割合が多くほぞ先端が土台に接触し、 めり込んだことで生じたと考えられる。 
表 3 実験結果（表記のない単位 : $\mathrm{N} / \mathrm{mm}^{2}$ 、カッコ内の数字 $\sigma \mathrm{y}$ は基準強度 $\times 2 / 3$ との比、 $\sigma_{20 \mathrm{~mm}}$ 時は基準強度との比、剛性は全面との比）

\begin{tabular}{|c|c|c|c|c|c|c|c|}
\hline \multirow[t]{3}{*}{ 製材 } & \multirow[t]{3}{*}{ 全面 } & \multicolumn{2}{|c|}{ 鋼板圧縮試験 } & \multicolumn{4}{|c|}{ 柱圧縮試験 } \\
\hline & & \multirow[t]{2}{*}{ 材端部 } & \multirow[t]{2}{*}{ 中間部 } & \multicolumn{2}{|c|}{ 材端柱 } & \multicolumn{2}{|c|}{ 中間柱 } \\
\hline & & & & ほぞ有 & ほぞ無 & ほぞ有 & ほぞ無 \\
\hline 基準強度×2/3 & 1.73 & 4.13 & 5.20 & \multicolumn{2}{|c|}{4.13} & \multicolumn{2}{|c|}{5.20} \\
\hline$\sigma_{\mathrm{y}}$ 平均 & $3.25(1.88)$ & $4.81(1.16)$ & $5.79(1.11)$ & $4.44(1.08)$ & $4.14(1.00)$ & $5.19(1.00)$ & $4.82(0.93)$ \\
\hline 変動係数 [\%] & 34 & 27 & 35 & 23 & 26 & 27 & 27 \\
\hline$\sigma_{\mathrm{y}} 95 \%$ 下限值 & $1.33(0.77)$ & $2.46(0.60)$ & $2.12(0.41)$ & $2.59(0.63)$ & $2.19(0.53)$ & $2.65(0.51)$ & $2.46(0.47)$ \\
\hline$\sigma_{\mathrm{y}} 50 \%$ 下限值 & $3.20(1.85)$ & 4.69 (1.13) & $5.60(1.08)$ & $4.34(1.05)$ & $4.04(0.98)$ & $5.06(0.97)$ & $4.70(0.90)$ \\
\hline$\sigma_{20 \mathrm{~mm}}$ 時 $95 \%$ 下限 & $2.21(0.85)$ & $5.79(0.93)$ & $5.91(0.76)$ & $4.84(0.78)$ & $4.33(0.70)$ & $6.15(0.79)$ & $5.72(0.74)$ \\
\hline$\sigma_{20 \mathrm{~mm}}$ 時 $50 \%$ 下限 & $4.94(1.90)$ & $11.27(1.82)$ & $9.05(1.16)$ & $7.72(1.25)$ & $7.44(1.20)$ & $10.32(1.32)$ & $9.82(1.26)$ \\
\hline$\delta_{\mathrm{y}}$ 平均 $[\mathrm{mm}]$ & 2.01 & 2.27 & 2.16 & 3.07 & 2.98 & 2.40 & 1.92 \\
\hline $\mathrm{K}_{\mathrm{c}, 90}\left[\mathrm{~N} / \mathrm{mm}^{3}\right]$ & 3.39 & $3.25(0.96)$ & $4.23(1.25)$ & $2.37(0.70)$ & $2.49(0.73)$ & $4.05(1.19)$ & $4.84(1.42)$ \\
\hline
\end{tabular}

\begin{tabular}{|c|c|c|c|c|c|c|c|}
\hline \multirow[t]{3}{*}{ 集成材 } & \multirow[t]{3}{*}{ 全面 } & \multicolumn{2}{|c|}{ 鋼板圧縮試験 } & \multicolumn{4}{|c|}{ 柱厓縮試験 } \\
\hline & & \multirow[t]{2}{*}{ 端部 } & \multirow[t]{2}{*}{ 中間部 } & \multicolumn{2}{|c|}{ 材端 } & \multicolumn{2}{|c|}{ 中間 } \\
\hline & & & & ほぞ有 & ほぞ無 & ほぞ有 & ほぞ無 \\
\hline 基準強度×2/3 & 1.60 & 3.40 & 4.40 & \multicolumn{2}{|c|}{3.40} & \multicolumn{2}{|c|}{4.40} \\
\hline$\sigma_{\mathrm{y}}$ 平均 & $2.84(1.78)$ & $4.35(1.28)$ & $5.23(1.19)$ & $3.98(1.17)$ & $3.98(1.17)$ & $4.51(1.03)$ & $4.17(0.95)$ \\
\hline 変動係数[\%] & 34 & 25 & 20 & 12 & 10 & 19 & 17 \\
\hline 管 $95 \%$ 下限值 & $1.16(0.73)$ & $2.38(0.70)$ & $3.34(0.76)$ & $3.12(0.92)$ & $3.26(0.96)$ & $2.96(0.67)$ & $2.89(0.66)$ \\
\hline$\sigma_{\mathrm{y}} 50 \%$ 下限值 & $2.79(1.75)$ & $4.25(1.25)$ & $5.13(1.17)$ & $3.93(1.16)$ & $3.94(1.16)$ & $4.43(1.01)$ & $4.10(0.93)$ \\
\hline$\sigma_{20 \mathrm{~mm}}$ 時 $95 \%$ 下限 & $4.75(1.98)$ & $6.75(1.02)$ & $9.83(1.93)$ & $8.45(1.66)$ & 6.77 (1.33) & $12.48(1.89)$ & $8.23(1.25)$ \\
\hline$\sigma_{20 \mathrm{~mm}}$ 時 $50 \%$ 下限 & $5.70(2.37)$ & $9.22(1.40)$ & $11.96(2.34)$ & $9.77(1.92)$ & $8.50(1.67)$ & $14.89(2.26)$ & $10.96(1.66)$ \\
\hline$\delta_{\mathrm{y}}$ 平均 $[\mathrm{mm}]$ & 0.89 & 2.20 & 2.11 & 1.77 & 1.46 & 1.41 & 1.30 \\
\hline $\begin{array}{ll}\mathrm{K}_{\mathrm{c}, 90} & {\left[\mathrm{~N} / \mathrm{mm}^{3}\right]}\end{array}$ & 2.84 & $2.73(0.96)$ & $4.20(1.48)$ & $2.45(0.86)$ & $2.88(1.01)$ & $3.76(1.32)$ & $4.03(1.42)$ \\
\hline
\end{tabular}

\section{3 比例限応力度}

表 3 に基準強度の $2 / 3$ と実験結果から求めた統計的下限值や平均 值などを示した。ここで比例限は、枠組壁工法構造計算指針 $\left.{ }^{8}\right)$ に記 載されている方法によって算出した。基準強度は文献 ${ }^{4}$ に記載され る繊維直角方向の值である。表中には、各試験体の比例限応力度に 対して、材料の基準強度の評価に用いられる信頼水準 $75 \%$ における $95 \%$ 下側許容限界值（以下、 $95 \%$ 下限值）と、耐力壁の短期許容 耐力の評価に用いられる同 $50 \%$ 下側許容限界值（以下、50\%下限値） を統計処理し、試験パラメータ毎に求めた值を示した。以上に加え、 基準強度との比較として、後述する振動台実験の結果を踏まえて提 案するめり込みの許容変形の $20 \mathrm{~mm}$ の応力度について比例限応力 度と同様に $95 \%$ 下限值と $50 \%$ 下限值について求めたもの、さらに、 降伏変位 $\delta_{\mathrm{y}}$ の平均、めり込夕剛性 $\mathrm{K}_{\mathrm{c}, 90}$ の平均を示した。比例限応 力度のカッコ内は基準強度の $2 / 3$ に対する比を示す。この比は現行 の基準強度との比と同意である。また、 $\sigma_{2} 2 \mathrm{~mm}$ 時のカッコ内は基準強 度との比を表している。

製材、集成材ともに、95\%下限值では基準強度を下回り、基準強 度には、平均值、あるいは $50 \%$ 下限值がほぼ対応していることがわ かる。変動係数は、全面圧縮と鋼板圧縮の端部は製材と集成材で同 じであるが、それ以外では製材が大きい。また、ほぞの有無では比 例限応力度では、ほぞ有の方が大きい傾向はみられるが、集成材の 材端においてはその差は顕著ではない。振動台実験の結果を踏まえ て提案する許容変形の $20 \mathrm{~mm}$ の荷重について全面圧縮を除いて、比 例限応力度と同じように $50 \%$ 下限值で比較すると、製材では 1.16 1.82 倍の、集成材では 1.40 2.34 倍の現行の基準強度に対し
ての割り増しが期待できる。また、剛性は、全面圧縮より端部は総 じて小さくなる傾向、中間部では、めり込みに対する端部の余長が あることで、全面圧縮と比較して製材で 1.19 1.42 倍、集成材で 1.32 1.48 倍となった。

\section{3.めり込みを強制的に生じさせた振動台実験}

\section{1 実験概要}

図 14 に実験方法を示す。加振によって、後述する柱付き壁（以 下、壁パネル）に水平力を与え、柱を土台にめり込ませるようにし た。壁パネルの幅は $910 \mathrm{~mm}$ であり、上部に載荷できる錘に限界が あるため、水平せん断力を増加させるために、壁パネルと並列にせ ん断抵抗のほとんどないフレームを用意し、その上に錘を載せ、フ レームで発生したせん断力が壁パネルに伝わるようそれぞれを溝形 鋼によってつないだ。壁パネル上部及びフレーム上の錘の重量は、 それぞれ約 $10 \mathrm{kN}$ とした。なお、フレームは柱横架材接合部をピン 節点に近づけ、せん断抵抗を生じにくくするため、柱頭柱脚接合部 の HD 金物のボルトの止め付け部分にワッシャー形状をした厚さ $16 \mathrm{~mm}$ ゴムを数枚挟んだ。加振は動的アクチュエータを試験体下部 のスライダーに取り付けることにより実施した。

壁パネルは、高さ $2,800 \mathrm{~mm}$ 、厚さ $105 \mathrm{~mm}$ 、幅 $910 \mathrm{~mm}$ で、カラ マツ集成材（同一等級構成集成材 E105-F300）を用いた。柱付き壁、 と前述したのは幅 $910 \mathrm{~mm}$ の両端の下部に柱形を模した加工を施し、 さらにほぞを切り欠いていることによる。つまり、柱と壁は一体で ある。土台は材料実験の集成材と同じ、オウシュウアカマツ集成材 （同一等級構成集成材 E105-F300）で、端部柱圧縮試験（以下、端 
部試験体）と中間柱圧縮試験（以下、中間部試験体）に相当する 2 種類を用意した。端部試験体では壁パネル幅と土台の木口面を揃え パネル幅と同じ長さ $910 \mathrm{~mm}$ とし、中間部試験体はめり込みに対す る土台の端部の余長を十分にとり土台全体の長さを $1,600 \mathrm{~mm}$ とし た。試験体数は大きなめり込み変形が予想される端部試験体を 3 体、 中間部試験体を 1 体とした。ほぞの加工は、前述した材料実験と同 じ仕様である。

ここで、壁パネルの縦横比を $3: 1$ 、すべての水平力を壁パネルが 負担するとの仮定のもとで $1 \mathrm{G}$ の加速度が作用した際には、壁パネ ルには $20 \mathrm{kN}$ の水平力が作用し、柱脚部には水平力によって $60 \mathrm{kN}$ の鉛直力と、載による鉛直荷重が片側の柱に $10 \mathrm{kN}$ の半分の $5 \mathrm{kN}$ 、 合計 $65 \mathrm{kN}$ の力が作用する。さらに、柱脚に取り付けた HD 金物の ボルトの初期時導入軸力は全加振において $10 \mathrm{kN}$ に統一しており、 合計 $75 \mathrm{kN}$ の力が作用する。応力度で端部試験体 $8.05 \mathrm{~N} / \mathrm{mm}^{2}$ 、中間 部試験体 $8.94 \mathrm{~N} / \mathrm{mm}^{2}$ であり、基準強度を上回る圧縮力が作用する。 よって、柱脚金物には短期許容耐力 $60 \mathrm{kN}$ の HD 金物を用い、ここ で想定している程度の圧縮力には耐えられるように設計した。また、 壁パネルのせん断強度 $\tau$ を $3.6 \mathrm{~N} / \mathrm{mm}^{2}$ と考えた場合、パネル本体の せん断耐力は $344 \mathrm{kN}$ と上述の $60 \mathrm{kN}$ に比べ、十分に余裕があるが、 柱やほぞ部分でのせん断耐力が不足する。そこで、土台下部から M12 ボルトを 3 本固定し、その上部を壁パネル脚部に埋め込み、せ ん断力を負担させることとした。

入力加振波は、建築基準法の極大地震を 2 種地盤で増幅したスペ クトルに合わせた人工地震動 9) (以下、BSL 波) と、1995 年兵庫 県南部地震の際に神戸海洋気象台で得られた地震波のうちの NS 成 分を用いた (以下、JMA 神戸)。徐々に外力を上げていく加振とす るため、入力倍率を調整し、BSL 波で $20 \% 、 100 \%$ の後、JMA 神戸 波で $70 \% 、 100 \% 、 125 \%$ の順で加振した。柱脚の圧縮力は、柱脚金 物を介したロードセルによって柱の引抜力を計測し、圧縮力との釣 合いが成立するものとして計算により求めた。

\section{2 実験結果}

表 4 に BSL $20 \%$ 加振以後の荷重変形関係、壁パネル脚部の柱形に よる圧縮応力度-めり込み関係、めり込みの様子を整理して示す。脚 部の圧縮応力度一めり込み関係は、めり込みが先行した柱側について 記載した。

加振と目視観察の結果 BSL20\%加振では、端部、中間部の両試 験体とも目視ではめり込みは見られなかった。その後端部試験体で は、BSL100\%加振でめり込みが顕著に見られ、材料実験のような 土台の面外方向へはらむような破壊が確認できた。また、土台にめ り込みが進展するにつれて上面にせん断キー設置用の座掘端部から ラミナの剥離が生じ、JMA 神戸波 $100 \%$ で過大なめり込みが生じ加 振終了とした。中間部試験体では、BSL100\%加振後に土台に目視 でめり込みが確認でき、JMA 神戸波 70\%、100\%加振とめり込みが 進展したが端部試験体に比べ軽微であった。その後 JMA 神戸 $125 \%$ 加振によって柱脚金物が破壊したため、試験終了とした。

全体の荷重変形関係と脚部のめり込み 壁パネルへの損傷は見ら れず、壁パネル自体は弾性と考えられるが、荷重変形としては非線 形挙動を示した。パネル自体の耐力が十分に確保されていることか らパネルの柱形が土台にめり込むことによる柱脚部の非線形化に起

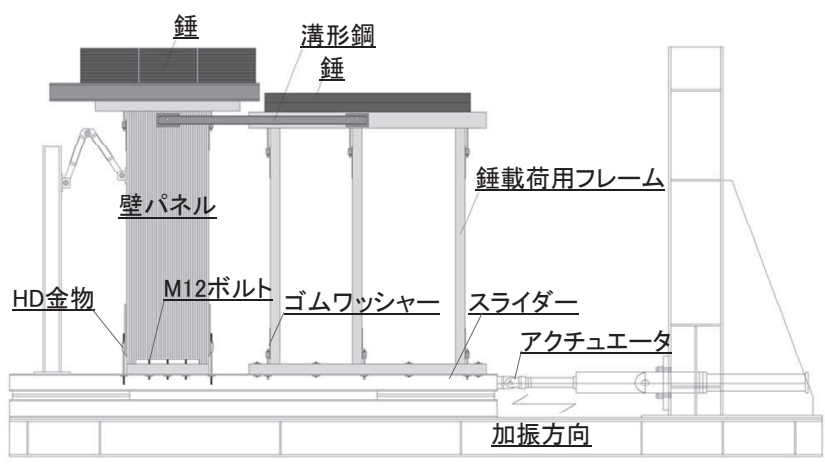

図 14 実験方法

因することがわかる。端部試験体では JMA 神戸 $70 \%$ で限界耐力計 算の安全限界である $1 / 30 \mathrm{rad}$ を超え、実験終了時に鉛直荷重支持能 力は保持していたものの、 $77 \mathrm{~mm}(1 / 36 \mathrm{rad})$ の残留変形が生じ大き な傾斜が残る結果となった。

圧縮力応力度-めり込み変位関係 図中に示したバイリニア曲線 は本実験に使用した土台近傍から切り出した材料実験より得られた 実験結果の平均值を示し、破線は基準強度である。極大地震である JMA 神戸 $100 \%$ 入力時に中間部試験体では耐力低下が見られなかっ たものの、端部試験体ではスリップ挙動が顕著で、最大点指向型の 履歴特性が崩れ、荷重低下がみられた。最大めり込み変位は、中間 部試験体では $8 \mathrm{~mm}$ 程度であるのに対し、端部試験体では $44 \mathrm{~mm}$ 程 度と 5 倍以上のめり込みが生じ、土台が大きく損傷した。

\section{4. めり込み基準強度の提案}

材料実験においてパターン(3)のような荷重低下がみられる以上、 終局状態、基準強度として何らかの制限が必要である。ただ、振動 台実験で基準強度の 2 倍程度の外力が作用したが、それによって安 全性、ここでは鉛直荷重支持能力のあることが確認できており、な んらかの緩和も一方で考えられる。

まず、材料試験においてパターン (3)が生じたのはめり込みが $40 \mathrm{~mm}$ を超えた後であるため、 $40 \mathrm{~mm}$ 以内が一つの指標である。つ いで、振動台実験において端部試験体の JMA70\%の際に大きな残留 変形が残る結果となり、この状態が終局状態に近い。その変位は $26.68 \mathrm{~mm}$ であった。また、端部試験体の BSL100\%と中間部試験体 の神戸 $125 \%$ 加振でそれぞれ、 $15.43 \mathrm{~mm} 、 13.63 \mathrm{~mm}$ のめり込みが 生じたが、土台に亀裂が発生や材のはらみが見られたが、まだ十分 に荷重上昇にある。そこで、ここでは荷重低下が生じる $40 \mathrm{~mm}$ に対 して十分の余裕のある $20 \mathrm{~mm}$ を提案する。ただし、めり込みが $20 \mathrm{~mm}$ 以内であっても壁の変形によって構造物としての危険性が生 じる可能性もあり、それについては別途検討が必要であることを念 のため申し添える。

\section{5.まとめ}

土台のめり込みに対し本研究で得られた知見を以下に示す。

1）弾性挙動の後降伏し、その後ハードニングが起こるもの、降伏後 の剛性で推移するもの、荷重が低下するものなど、めり込み挙動 は異なったが、今回実施したすべての試験体の最大応力度は、基 準強度を上回った。 
表 4 荷重変位関係・柱脚部の圧縮応力度および破壊の様子

端部試験体

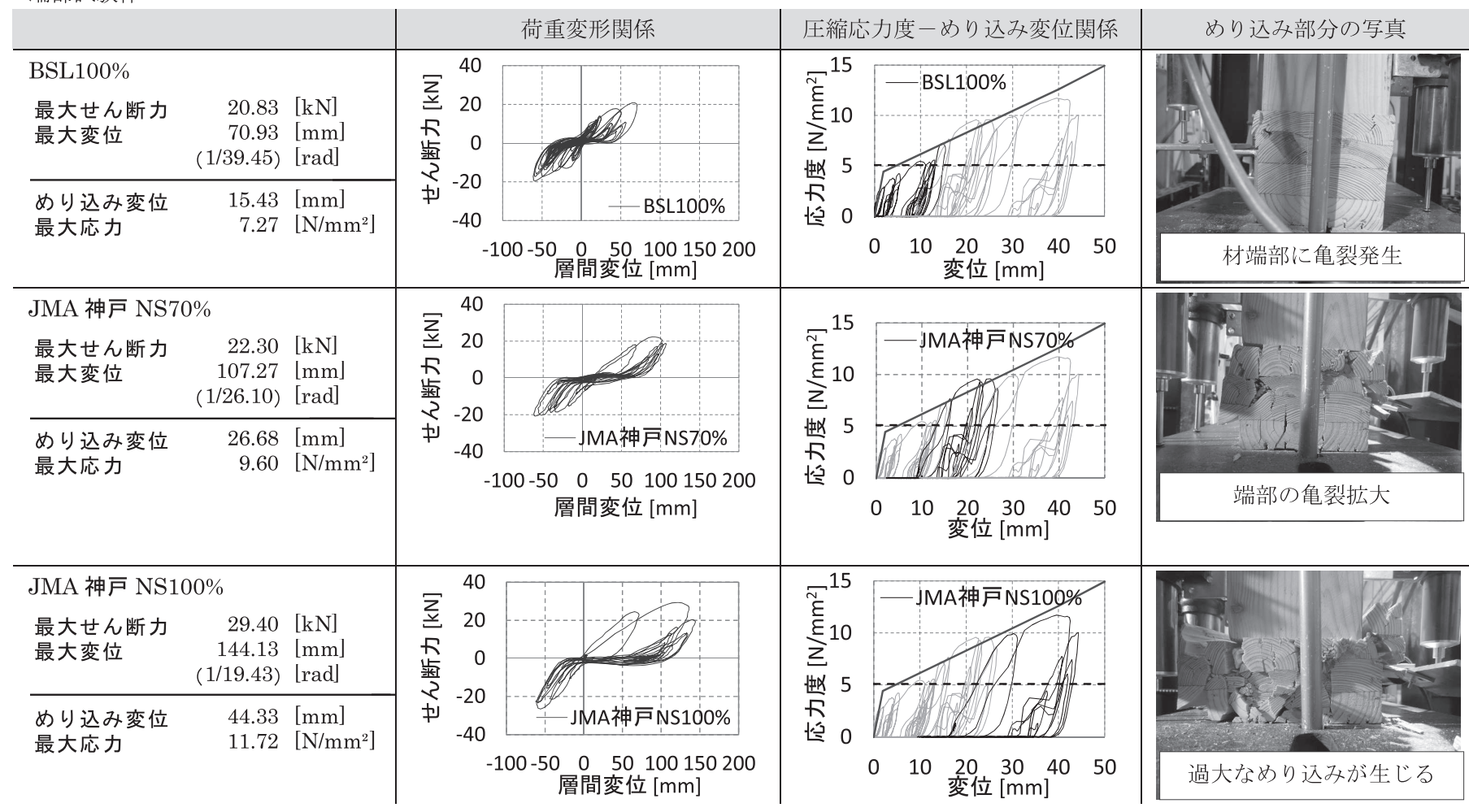

中間部試験体

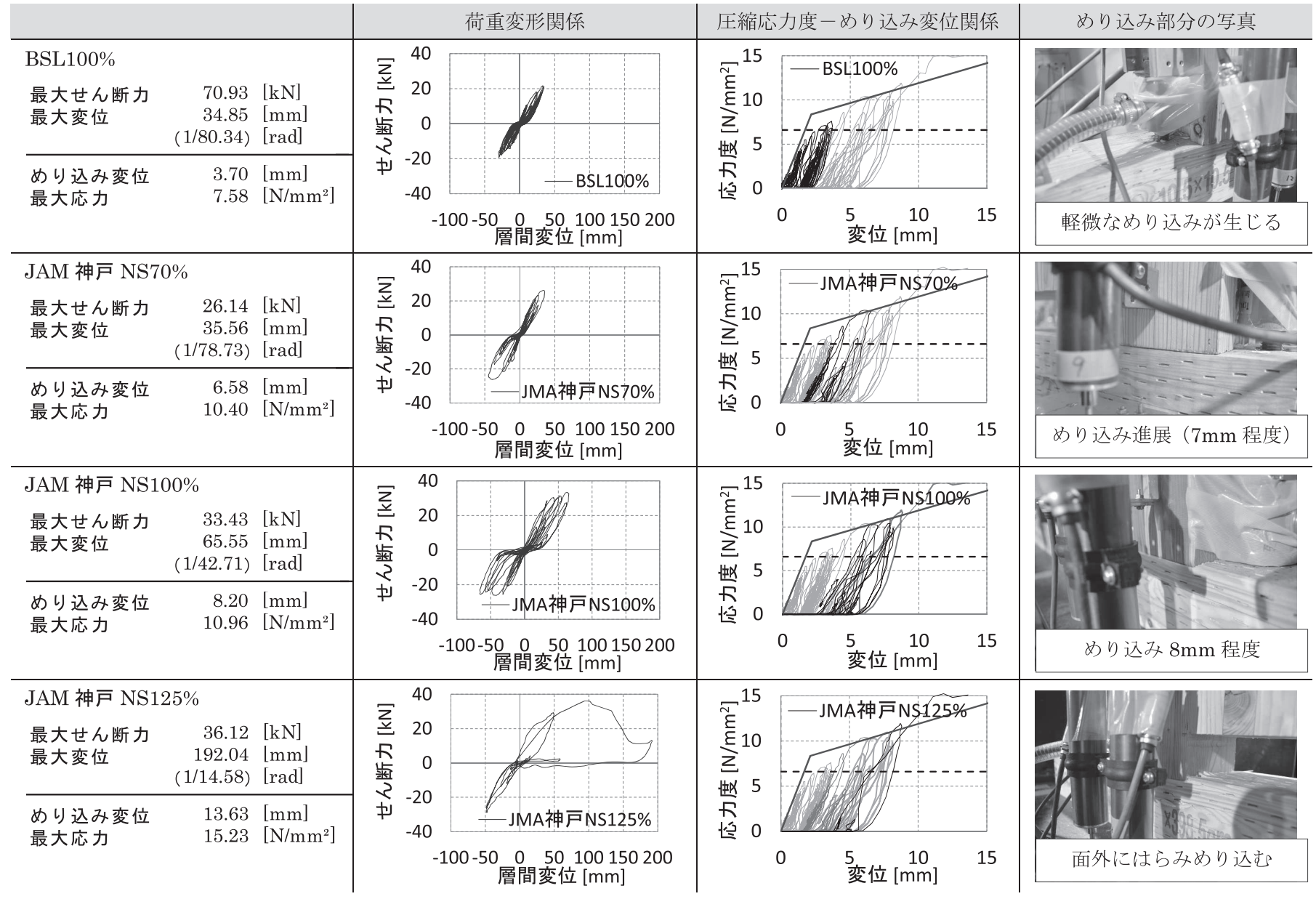


2)材料実験で得られためり込み $\sigma_{\mathrm{y}}$ の平均值、あるいは信頼水準 $75 \%$ における $50 \%$ 下限值が、基準強度を $2 / 3$ 倍した值とほぼ一致した。 全面圧縮試験は実験值のそれらが、基準強度の 1.8 倍程度高かっ た。

3)振動台実験において、土台の端部に柱が配置される試験体、土台 の端から十分な余長が確保されている試験体ともに基準強度の 2 倍程度の外力を作用させたが、試験体上部の錘を支えられなくな るような鉛直荷重支持に問題があるような現象は見られなかった。 4)材料試験と振動台実験の結果を踏まえ、土台の基準強度の指標と なる変形として $20 \mathrm{~mm}$ を提案した。許容変形 $20 \mathrm{~mm}$ 時の応力度 の平均值は、現行の基準強度と比較し、製材では 1.16 1.82 倍の、 集成材では 1.40 2.34 倍の現行の基準強度に対しての割り増しが 期待できる。

なお、同じ材から切り出した試験体であっても、めり込み応力度 一変形挙動に違いがみられた。さらに、ほぞのある試験体のうち集 成材では、変形が $10 \mathrm{~mm}$ 程度の時に荷重の上昇がみられ、製材では その挙動は確認できなった。これらは今後詳細な検討によって明ら かにする予定である。加えて、今回は下部に基礎支持のある土台を 扱ったが、一般のはりにおいて、材の残留変形を伴うような外力を 終局状態として許容できるか、については今後検討が必要である。

\section{謝辞}

本研究は、平成 $24 \sim 25$ 年長期優良住宅 構造・材料分科会の一環 として実施した。室井祐弥君（当時信州大学修士課程）に実験に協 力いただきました。この場を借りて感謝します。

\section{参考文献}

1）稲山正弘：木材のめり込み理論とその応用一勒性に期待した木質ラーメ ン接合部の耐震設計法に関する研究一, 東京大学博士学位論文, 1991.9

2）野口弘行, 橋爪靖彦: 有限要素法を用いた木材のめり込み規定に関する 解析的考察一木材の繊維方向に直角方向の圧縮に関する研究一, 日本建 築学会構造系論文集 第 491 号, pp.81-87, 1997.1

3）棚橋秀光，清水秀丸，鈴木祥之：パステルナーク・モデルに基づく直交 異方性木材の部分圧縮による弾性表面変位，日本建築学会構造系論文集 第 609 号, pp.129-136，2006.11

4) 日本建築学会 : 木質構造設計規準・同解説, 2006.12

5）日本建築学会 2014 年木質構造 PD : 木造から木質構造へ 10 の理論、 10 の技術、材料の理論、2014.09

6)（財）日本住宅・木材技術センター：木造軸組工法住宅の許容応力度設計 (2008 年版), 2008

7）（財）日本住宅・木材技術センター：構造用木材の強度試験マニュアル 2011.3

8）社団法人・日本ツーバイフォー建築協会編 : 枠組壁工法建築物構造設計指 針, 2007

9）清水秀丸, 三宅辰哉, 西沼裕介, 羽田竜介, 五十田博, 槌本敬大, 河合 直人 : 木造 3 階建て軸組構法住宅の設計法と振動台実験, その 3 , 建物 重量と入力波, 日本建築学会大会学術講演梗概集, C-1 分冊, pp.223-234, 2010.8 


\title{
RESISTING PERFORMANCE AND FRACTUAL BEHAVIOR BY SILL EMBEDMENT DURING EARTHQUAKES
}

\section{Sho AKIMOTO *, Hiroshi ISODA **, Masahiro MATSUDA *** and Takahiro TSUCHIMOTO****}

\author{
* (Former) Grad. Stud., Graduate School of Engineering, Shinshu University \\ ** Prof., RISH, Kyoto University \\ Visiting Researcher, BRI, Dr.Eng.
}

*** Assist. Prof., Faculty of Eng., Shinshu University, Dr.Eng.

**** Chief Research Engineer, Dept. of Building Materials and Components, Building Research Institute, Dr.Agr.

Characteristic of partial compression perpendicular to the grain is known as having a high ductility comparing with compression parallel to the grain, bending and tension. Experimental and theoretical studies have been carried out to evaluate strength and stiffness and consider the structural design. The current strength value is derived from the experimental study. It is difficult to define the strength directly in the compression perpendicular to the grain due to hardening in the final stage of compression test. The strength is defined as the 1.5 time of yield strength of the tests. As the results of the behavior of normal partial compression, confirmation to the partial compression can be ignored in the in the allowable stress design for wooden house. But we don't have enough data for them in the severe compression and when displacement is given to the specimen until $20 \mathrm{~mm}$ in the condition of standard testing method, the strength of 1.5 times of yield strength is not always obtain from the test. To avoid the damage during moderate earthquake, the limit of strength is also required.

In this study, many partial compression tests under large deformation were conducted to grasp the damage and safety limit and to evaluate the strength value. The specimen consists of full surface, edge part and center part compression of the sill with/without column and so on. The shaking table tests were also conducted to confirm the damage and safety limit. Results of these static and dynamic loading tests are summarized as follows;

1) The strength obtained from all material tests is satisfied with the strength value in accordance with Japanese Building Standard Law, but the strength in a few of full surface compression dropped the load after the given deformation of $60 \mathrm{~mm}$.

2) Safety capacity for supporting vertical load is confirmed under more than strength value in the shaking test. Safety limit deformation is proposed around $20 \mathrm{~mm}$ and it is $1.16-1.82$ time of timber and 1.40 to 2.34 times of glulam in the current strength. 